Оригинални научни рад

УДК 821.163.41.09-31 Киш Д.

Примљен: 31. марта 2021.

Прихваћен: 17. априла 2021.

Маша Р. Станишић ${ }^{1}$

https://doi.org/10.46630/phm.13.2021.15

Универзитет у Нишу

Филозофски факултет

Департман за србистику

\title{
СЛИКЕ С ПУТОВАЊА У ПЕШЧАНИКУ ДАНИЛА КИША
}

У раду ћемо са когнитивног аспекта, полазећи од појмовне метафоре ЖИВОТ ЈЕ ПУТОВАњЕ, роман Пешчаник читати као књигу о путовању, а путовање, које је стални мотив епике, сагледати као вид јунакове потраге за изгубљеним сопством. Е. С. је путник који, крећући се светом приче романа, говори о себи, о својим жељама, надама, склоностима, ставовима према животу, о свом интимном свету, страховима, приказујући историјску истину епохе коју су обележили ужаси Другог светског рата. Дестинација Е. С.-а, односно крајње исходиште његовог путовања, креирано је у свести јунака као дуго плутање по таласима вечности чиме је истакнута ахасверска природа јунака и у смрти.

Кључне речи: појмовна метафора, књига о путовању, идентитетска потрага, Пешчаник, Данило Киш

Путовање је стални мотив епике од њеног настанка и због тога је често случај да се она дела уметничке литературе у чијем је средишту кретање јунака кроз простор и време називају путописном књижевношћу (POPOVIĆ 2007: 592). Јан Борм (Jan Borm) у тексту Одређивање пута: о путопису, путничкој књижевности и терминологији настоји да докаже да путничка књижевност није засебан жанр „већ (да) је у питању колективни термин који обухвата разноврсне текстове с тематиком путовања, без обзира да ли су преовлађујуће фикционалне или нефикционалне природе" (BORM 2013: 607). Путописац, приказујући предмет свог интересовања (свет, путовање), рекреира свет који приказује и кроз њега говори о себи, износећи своје ставове према животу, уметности, култури, откривајући свој осећајни свет. Жан Рудо (Jean Roudaut) одреЂује путопис као дисконтинуиран текст мозаичке форме:

„Он подређује делове текста који се међусобно разликују у

1 masastanisic1982@gmail.com 
тону... Текст је стратификован: састоји се из различитих слојева гласова, речника (описи варирају у врсти: пејзажи, описи насеља, одеће, делатности) и стила... Путопис комбинује хетерогено (користећи истовремено облик мемоара, дневника и писма) и диспаратно. Путопис тежи мозаику" (BORM 2013: 613).

Мери Бејн Кембел (Mary Baine Campbell) ће о путопису рећи да је то „жанр компонован из других жанрова, при чему је и сам снажно допринео генези модерног романа и препороду аутобиографије” (BORM 2013: 608). Говорећи о приближавању путописа роману, Миливој Солар разлог види у могућности за „шире уметничко обликовање запажања, дојмова, размишљања, о свему оном што путописца заокупља током путовања" (SOLAR 2005: 225). Нортроп Фрај пишући о миту и архетиповима у књижевности, архетип путовања сагледава као вид потраге: „Централни мит књижевности, у свом наративном аспекту, идентификовали смо с митом о трагању" (FRAJ 1981: 128).

Роман Пешчаник Данила Киша разрађује тему путовања по успоменама и сећањима која су подстакнута документима, од којих је писмо, које је у структури романа заузело епилошку функцију, најважнији. Пешчаник је роман са наглашеном путописном димензијом: главни јунак Е. С. путује и физичким простором света приче и менталним простором сећања, конструишући контрачињеничне дестинације (обећана земља), приближавајући се, заправо, коначној дестинацији коју ће у једном од својих екстатичних размишљања приказати себи као „дуго плутање по таласима вечности" (KIŠ 1972: 277). Е. С. ће и смрт видети као путовање (по таласима вечности).

Путовање је код Киша повод за ширу фабуларизацију документа/писма у оквиру мозаичке форме романа, који је сачињен од фрагмената којима је форму дао приповедач/приређивач, ${ }^{2}$ изграђујући појмовну метафору ${ }^{3}$ живот ЈЕ ПутОвАњЕ у оквиру које долази до пресликавања у

2 Романом Пешчаник, Данило Киш увео је новине у приповедање. Причу је раздвојио на четири приповедна тока који репрезентују туђе текстове - записе, описе, белешке и на крају једно писмо - чијим се укрштањем гради нова слика о губитку оца (JERKOV 1991: 107). Позиција приповедања у Пешчанику је истраживачка - треба приредити и објавити документе, последње белешке Е. С.-а, које су као тестамент остављене сину (да би се приближио ишчезлом лику оца), али приређивач пред собом нема јединствену исповест (JERKOV 1991: 107). Различити токови докумената који су укључени у Пешчаник сугеришу нам да прича не постоји пре него што је приповедач изгради - тек кад приређивач/приповедач суочи разнолике рукописе „пред њим се појављује ишчезла фигура оца, као ишчезли лик романа о његовом нестанку” (JERKOV 1991: 107). Ова двострука реконструкција, којом је судбина књижевног облика везана за судбину јунака, аутентична је форма коју су фикционални свет и судбина главног лика захтевали (JERKOV 1991: 107).

3 О метафори су са когнитивног аспекта први писали Џорџ Лејкоф и Марк Џонсон у 
метафоричним доменима: путник је човек који живи; превозно средство је сам процес живљења; путовање је једнако догађајима у животу путника; пређени пут једнак је учињеном напретку; препреке на које се наишло јесу тешкоће са којима се путник суочио; одлуке којим путем кренути јесу избори шта учинити, а дестинација је судбина и на крају смрт. ${ }^{4}$ Ако схватимо путовање као потрагу (према Фрају), односно као потрагу за изгубљеним сопством, како га сагледава Снежана Милосављевић Милић (DIMITRIJEVIĆ 2012: 287), Е. C. (епистоле састављач) је у Пешчанику путник који иде ка својој судбини, откривајући успут најдубље тајне свог бића, а роман Пешчаник можемо читати као књигу путовања Е.С.-а кроз призму идентитетске потраге.

Слике с путовања, назив је једног од четири тока романа, који има есејистички карактер, а у нашем раду овим ћемо називом обухватити исечке из живота и сећања путника Е. С.-а којима ћемо илустровати горе наведене домене, аргументујући примењивост појмовне метафоре живот ЈЕ ПУТОВАњЕ на интерпретацију романа Пешчаник као књиге о путовању.

Путник - човек који живи, приказујући свет којим се креће кроз доживљаје са путовања говори о себи, о својим жељама, надама, склоностима, ставовима према животу, о свом интимном свету. Е. С. је представник средњоевропског јеврејства, верско-социјалне групе која је у време Другог светског рата преживљавала прогон и погром. Он је муж, отац и индивидуа располућена страхом од смрти. Виталистички став према животу и страст према путовању обликоваће његов сан о бекству из ужасне историјске и животне ситуације у којој се нашао. Уметничке склоности јунака (писац је романа Парада у харему и аутор је Кондуктера - књиге намењене путницима), укус и културне норме (не одриче се реквизита грађанске класе: шешир са тврдим ободом, штап, крагна од каучука, актенташна), навике (да путује купеом прве класе), додатно ће га издвајати из средине у коју се, у новонасталим околностима, не уклапа и доводиће га у понижавајуће ситуације (истеривање из купеа прве класе).

Све што се у роману догађа, приметио је Јован Делић, догађа се у јунаковој свести у току једне ноћи, док он, пишући Писмо, прелистава своје концепте и своје Белешке једног лудака, док му се у сећању јављају „слике с путовања” или му се враћа у свест „саслушање сведока” (1997: 254). Роман Пешчаник осветљава свест главног јунака, а сва збивања и догађаји предочени у роману, развијени су на менталном плану Е. С.-а виртуелни су. Јунакова свест прожета је контрачињеничним пројекцијакњизи Metaphors We Live By (1980).

4 Схему појмовне метафоре ЖИВОТ ЈЕ ПУТОВАњЕ преузели смо из рада Михајла Антовића: Teorija optimalnosti i teorija metafore u svetlu muzičke i jezičke kompetencije (ANTOVIĆ 2007: 160). 
ма чудесних избављења њега и његове породице, али и пројекцијама сопствене смрти. Самосагледавање насмрт преплашеног јунака, уроњеног у сопствени интимни простор и ствари које се у њему налазе, одсликава емотивни и вредносни простор Е. С.-а у Пешчанику.

Прогонство које доживљава Е. С. двоструко је: прогон из дома и претња смрћу (прогонство из живота). Путнику је дом референтна тачка. У дому се очитавају категорије стабилности и сигурности, а Е. С. је истеран из дома, што ће бити узрок његове носталгије. ${ }^{5}$ Јунак се у фијакеру и у купеу прве класе осећао као код своје куће (пореди се са путницима Нојем и Мојсијем). Прогоњени је у сталној потрази за склоништем (за домом), који ће покушати да пронађе у дубини свог унутрашњег света.

Простор куће (дома) можемо посматрати башларовски као простор уточишта за биће, безбедно место, скровиште, интимни простор који чува целовитост бића, интегришући, кроз сањарења, мисли, сећања и снове (BAŠLAR 2005: 30). ${ }^{6}$ Селидбе у све гора и гора места становања, након што је јунак био приморан да напусти кућу у Бемовој улици, одсликавају и физичко и ментално пропадање јунака. Кућа у Бемовој, која се срушила након што је Е. С. из ње изнео и последњи комад намештаја, идентитетски је означитељ јунака - темељ куће положен је истог дана када је рођен Е. С. и њено рушење приказује, у пренесеном смислу, урушавање, дезинтеграцију индивидуалног идентитета јунака.

„(К)ада, дакле, неко с носталгичним погледом последњи напусти свој стан, а кућа се у том тренутку потресе из темеља, жестоко, као под теретом погледа, под теретом свих недаћа које су се у том стану кондензовале годинама (његове и туђе несреће), држећи трошну празнину трошних зидова, испуњавајући просторију својом густом масом, под теретом несрећа и мисли које ту беху затворене као у вакууму, згуснуте до експлозије, и које су наједном покуљале, шикнуле на све стране, у страшној експлозији коју је изазвао тај његов поглед бачен презриво као горући чик у јаму са земним гасом сред панонског блата” (KIŠ 1972: 113).

Услед потребе за уточиштем (за себе и своју породицу) Кишов јунак, подстакнут идејом о сопственој посебности, коју подупире митска прошлост народа којем припада, конструише слику о себи као о припад-

5 Светлана Бојм (Svetlana Boym) носталгију дефинише као чежњу за домом који више не постоји или никада није ни постојао (види ВОЈМ 2007).

6 „(К)ућа (је) једна од највећих сила интеграције за мисли, за сећања и снове човека. Спајајући принцип у тој интеграцији, то је сањарење. Прошлост, садашњост и будућност дају кући различите динамизме који се често мешају, сударајући се понекад или изазивајући се међусобно. Кућа у животу човека одстрањује неизвесности, она у изобиљу пружа своје савете континуитета. Без ње би човек био разбијено, расуто биће. Она подржава човека кроз олује неба и непогоде бића. Она је тело и душа" (BAŠLAR 2005: $30)$. 
нику изабраног народа.

Превозно средство - сам процес живљења Е. С.-а у историјском тренутку у којем отпочиње писање писма, које ће послужити приповедачу да реконструише јунаков живот, асоциран је у прологу романа собомбарком у коју ударају таласи ноћи (мрак историје из којег вребају опасности). Соба у којој се налази Е. С. осликана је као чамац који тоне, у којој тиња гребенасти пламен (симболише свест) који је на издисају, али не дозвољава да собу-барку испуни мрак. Пламен лампе, као „око отворено у кући” (BAŠLAR 2005: 53) открива ствари и њихов специфичан распоред који јунаку пружа утисак сигурности и стабилности. Од првих страница романа читалац доживљава живљење Е. С.- а као лутање.

Путовање је једнако догађајима у животу путника, односно сећању на догађаје. Е. С. је стално на путу, а железничка станица, воз, путовање, метафоре су потраге за изгубљеним сопством (DIMITRIJEVIĆ 2012: 287). Воз тумачимо као хронотоп пута, који је, према Бахтину, уско повезан са хронотопом случајних сусрета, који ће бити прекретнице у животу јунака (истеривање из купеа прве класе, сусрет са Црном Госпом). Хронотоп сусрета у коме преовладава временска нијанса одликује висок степен емоционално-вредносних интензивности, док са њим повезан хронотоп пута има шири обим, али нешто мању емоционално-вредносну интензивност (BAHTIN 1986: 355). Пут је, према Бахтину, најчешће место случајних сусрета. ${ }^{7}$

Током путовања возом, јунак ће доживети два интензивна животна искуства, која ће дуго одјекивати у његовој свести - истеривање из купеа прве класе и сусрет са Црном Госпом у чијем лику су сублимирани ерос и танатос, два пола човековог искуства између којих се креће јунак: „Ко је стајао пред њим у том часу?

Млад плавокос кондуктер који бејаше уперио своја никлена клешта у његове груди, у његову звезду, као револвер.

Ко је посматрао овај призор, осим кондуктера и оног који покушава (видећи себе) да закопча своју актаташну?

Госпођа са шеширом и велом преко лица (око тридесет година) која је привијала уза се заспалу девојчицу (око три године), као да ће се у

7 „На путу се у једној временској и просторној тачки секу просторни и временски путеви различитих људи, представника свих сталежа, стања, вере, националности, узраста. Овде се случајно могу срести они који су нормално раздвојени друштвеном хијерархијом и просторном удаљеношћу, овде могу настати свакојаки контрасти, срести се и сплести се различите судбине. Овде се на свој начин стапају просторни и временски низови људских судбина и живота, осложњавајући се и конкретизујући се друштвеним дистанцама, које се овде руше. То је и тачка заплета и место збивања догађаја. (...) Пут је нарочито погодан за приказивање догађаја које усмерава случајност" (BAHTIN 1986: 355). 
возу, у купеу прве класе брзог воза, догодити сада нешто страшно, крв и злочин, као у роману;" (КIŠ 1972: 75).

Ови догађаји имаће реперкусије и на јунакова каснија путовања (нека друга госпа у црнини, подсетиће га на фатални сусрет).

Опис сапутника и догађаја из купеа, посебно госпе у црнини, коју ће назвати Удова белих удова, откривају јунаков доживљај путовања, његов осећајни свет, укус, скривене жеље и страхове, као и однос према животу. Е. С. ће развијати у мислима контрачињенични наратив о томе како је Госпа обудовела и обратиће пуну пажњу на њену црнину: хаљину (сигурно из најновијег модног журнала) вео, чипку комбинезона, посебно на свилене чарапе које ће му распламсати машту због чега ће се ставити у ривалску позицију са младићем, сапутником, који је према мишљењу Е. С.-а први могући љубавник Црне Госпе.

Сусрет са Црном Госпом и изгон из купеа прве класе тематизују, с једне стране виталистички принцип, који „Едуарду Саму омогућава да целокупну стварност доживљава страсно, сензуално, еротично и да у њој непрестано види могућност за испољавање властитог ероса и властите индивидуалности" (NEDIĆ 2002: 147-148), а с друге стране приказују гушење те индивиуалности и личне слободе. Њена коротна црнина слутња је смрти које се јунак боји. У сцени изгона из купеа прве класе, наглашава Делић, најбоље је илустрован антисемитски дух времена (DELIĆ 1997: 258).

Железничку станицу, на којој ће Е. С. поново видети Госпу и поздравити је наклоном (који она неће ни приметити), можемо интерпретирати као почетак новог и крај пређашњег пута, или као раскршће (животно): „Овде време као да се излива у простор и тече по њему образујући путеве” (BAHTIN 1986: 355), отуда разне метафоризације пута (животни пут, ступити на нов пут) - а основно језгро је, каже Бахтин, протицање времена (1986: 355). На јунака Пешчаника, међутим, ово раскршће одразиће се тек у сну у коме Е. С. види „васкрслог” младића који протестује против трговине људским костима, јер је он жртва костокрадица и моли Е. С.-а да обелодани свету страшну истину о међународној организацији костокрадица. Сан представља, с једне стране слутњу смрти Е. С.-а, односно нестанка у концентрационом логору у крематоријуму, а с друге стране Киш слика „историјску истину” епохе. Јован Делић ће рећи да је „међународна организација костокрадица” несумњиво фашизам (DELIĆ 1997: 259).

Препреке представљају тешкоће са којима се путник суочио, а највећа међу њима јесте рација за време новосадских Хладних дана у коjoj је Е. С. ухапшен и одведен на губилиште, одакле се чудом спасао. Догађај који је био преломан за јунака, који је и узроковао бег код рођака 
на село - новосадска рација, током које је велики број Срба, Јевреја и Рома убијен на Дунаву, обавијен је елипсом, а приказане су његове последице. Бројне жртве дунавског масакра продефиловаће каталогом јунака којих he се Е. С. и Гавански у разговору сећати, а на самог јунака догађај ће, сазнаћемо то из Бележака једног лудака, оставити озбиљне психичке последице: „То осећање да ме је напустило моје сопствено Ја, то виђење себе из аспекта неког другог, тај однос према себи као према странцу ${ }^{\star 8}$ на Дунаву док сам стајао у реду. То бејаше исто ово осећање: с једне стране Е.C, педесет и три године, ожењен, отац двоје деце, размишља, пуши, ради, пише, брије се машиницом за бријање, а с друге стране, крај њега, заправо у њему самом, негде у средишту мозга, као у сну или полусну, живи неки други Е. С, који јесте и није Ја (...)" (КIŠ 1972: 154).

Јунаково предвојено Ја, које ће сам Е. С. назвати својим Ја-не-ја, дели мисли његовог мозга, а кобна мисао која га заокупља јесте мисао о смрти и јунаково путовање ће у великој мери бити подстицано бежањем од смрти.

Рат, фашизам, антисемитизам који су довели до прогона јунака и његове породице, представљају тешкоће на ширем плану света приче у контексту историјске трагедије. Сукоб са рођацима, с друге стране представља план личне трагедије која ће притискати јунака у оквиру породичног дома. Себични и неосетљиви рођаци који су, мислио је Е. C, бесправно присвојили и протраћили део његовог наследства, шиканирају породицу Сам јер Е.С. неће да учествује у њиховој мутној трговини. После свађе око крпљеног шпорета, који није хтео да прихвати, рођаци су му забранили да на њиховом шпорету угреје јело, што је проузроковало хладно-млечни Ускрс породице Сам.

Припрема за Ускрс и посета месарници, у којој је Е. С. купио килограм свињетине приметивши на лицу месара упитан поглед: „Зар ви, господине, једете свињетину?” (КIŠ 1972: 45), чиме је сугерисано да је антисемитски оријентисано друштво Е. С.-а одредило као Јеврејина. Свињетину коју је купио успут је „изгубио” што је објаснио судбином живот је пас и све је пождерао. Јунакова свест намучена је највише чињеницом да његова породица гладује и ова фрустрација призива у његову свест могуће последице (смрт целе породице, убиство рођака, прихватање мутних послова). Неправду од стране рођака Е. С. доживљава као нехуман однос према целој његовој породици - уступили су им зграду која је некад била коњушарница; гостиће се за празничном трпезом док јунакова породица гладује.

Пређени пут јесте учињени напредак на животном путу, који је начинио јунак прешавши преко препрека. У роману је превазилажење

8 * Недовршено. Недостаје један лист (КІŠ 1972: 154). 
препрека често мотивисано чудом или случајношћу, али је чешће случај да препреке спутавају јунака који кружи без постизања циља, што обесмишљава његово кретање и узрок је репетитивних мисли које га опсегају. Чудесно спасење (залеђена рупа у Дунаву није могла више да прима тела убијаних) и бекство у Керкабарабаш код рођака примери су превладавања препрека и кретања напред. У једном таквом тренутку јунак ће осећати снагу митског хероја. Током путовања фијакером према Бемовој улици, Е. С. уснуо сања:

„Плива у некој великој води, у потпуној тами, али свестан, у сну, сваког тренутка, да је спасен, као Ноје, и да су сви они који су били с њим до малочас потонули, да је, дакле само он надживео велику хаварију, што га је у сну испунило осећањем неког мутног поноса, јер то што се он спасао, једини, не бејаше само дело божје милости, него и део његових сопствених заслуга, његове спретности да се снађе у тешким животним ситуацијама" (КIŠ 1972: 83).

Сан се прекида у тренутку када је његова барка из сна, корабља, ударила у чврсто копно јер је фијакер нагло заокренуо, што симболише већ очврсли правац историје који се не може заобићи. Све човекове заслуге и способности ништавне су пред олујом историје, која ће затрти јунаков пут. Е. С. ће своје земаљско путовање завршити у концентрационом логору.

Одлуке којим путем кренути јесу животни избори јунака, а таквих избора било је мало за Е. С.-а. Чинило се да је постојао само један избор: да бежи и да преживи (и да спаси породицу) или да се препусти погрому. Неке од одлука које је на путу донео биле су условљене случајностима или непредвиђеним новим препрекама:

„Какву је одлуку донео пред бројем 21 у Бемовој (раније Немачкој) улици?

Нагло је променио своју ранију одлуку и рекао кочијашу да га сачека, jep ће се одмах вратити.

Шта је условило ову промењену одлуку?

Наглу одлуку да не сврати до своје станодавке (гђе Месарош) условило је ваљда због закашњења до којег је дошло на станици, као и сазнање да је сувише касно за посете" (KIŠ 1972: 84).

Одлази код свог пријатеља и бившег колеге Гаванског, не подмиривши дугове за стан, што му је била првобитна намера како би уверио станодавку „да не избацује његове ствари до прекосутра, када ће се коначно иселити" (KIŠ 1972: 84). Током разговора са Гаванским о људима које су обојица познавали, израста каталог ликова и различитих, углав- 
ном несрећних људских судбина, који ће додатно осветлити историјски тренутак и дочарати апокалиптични дух времена. Из разговора двојице пријатеља сазнајемо опширније и о друштвено-политичкој ситуацији у свету у време Другог светског рата, али и о полицијском часу заведеном у то време у Новом Саду.

Дестинацијом путовања можемо сматрати судбину јунака и, на крају, смрт. Бројне су контрачињеничне дестинације о којима Е. С. размишља и које прижељкује, али су бројне и оне којих се прибојава.

Јунак Пешчаника је метонимијска замена за средњоевропске јевреје којима се претило истребљењем. Е. С. је асоциран са Мојсијем, он је вођа Егзодуса, повлачи се са породицом од једног до другог склоништа сањајући „обећану земљу”, у којој неће бити прогоњен, прижељкујући чудо и небески знак који би га охрабрио у акцији:

„Жестока противофанзива савезника (...) истовремени атентат на вођу Рајха и остале главешине сила Осовине (...) проналазак од стране Савезника неког супертајног оружја, нервног гаса или неког другог отрова који би бар двадесет и четири часа држао у несвести или у потпуном бунилу непријатељске војнике; погодба на основу које би Савезници трампили заробљене официре и војнике за живот Жидова (...) Дозвола за исељење Јевреја у неку афричку земљу или на неко пусто острво (...) киднаповање вође Рајха (...) за чији би се живот тражила гаранција о слободном исељењу Јевреја из дијаспоре у САД, Канаду, Палестину или неку афричку земљу; спуштање неког оштећеног савезничког авиона (...) који би током ноћи био поправљен, а ујутру се винуо заједно са њим (Е. С.) и његовом породицом ка неком аеродрому изван домашаја зла (...) неки небески знак који би му указао на конкретну могућност спасења: глас који му у сну казује (горући грм) место где се спустио авион по њега или где је пристала подморница (Нојев ковчег)" (КIŠ 1972: 129-130).

Обећана земља је за јунака Пешчаника далека и недостижна, и у својим буновним мислима Е. С. настоји да ту земљу конкретизује као далеку Америку или Африку или митску Палестину, смишљајући чудесне околности које би га одвеле тамо.

Сигурности своје барке-собе, Е. С. ће се окретати у тренуцима наде, али и у тренутку очаја. Не пронашавши свој брод спаса, Е. С. своје смртно тело види као корабљу која ће дуго лутати ништавилом, при чему је мотив Нојеве барке, која је прикупила у себе остатке и специмене прошлости, трансформисан у мотив погребног ковчега: „Мој леш ће бити моја корабља, а моја смрт дуго плутање по таласима вечности. Ништа у ништавилу" (KIŠ 1972: 277). У покушају да се супротстави ништавилу, да прокријумчари у вечност све што му је за живота било блиско, како не 
би био сам у смрти, Е. С. развија метафору о Нојевој барци спаса. Дуго плутање по таласима вечности је слика смрти коју креира Е. С. у својој оптерећеној свести, истичући своју ахасверску природу и у смрти.

Свет приче (storyworld), концепт који је у наратологији понудила Мари-Лор Рајан (Marie-Laure Ryan), подразумева простор, који насељавају егзистенти и у којем се одвијају догађаји. Простор фикције је уметнички простор и његова топографија је фиктивна, нема референцу у стварном свету. Чак и када укључује топониме из реалног света, они су уметничком транспозициом промењени и у функцији су приче, или представљања ликова. Уметнички простор романа Пешчаник на ширем плану обухвата фикционални конструкт Средње Европе трансформисан у Пешчанику у културни и цивилизацијски мит, који је потонуо у „копненом потопу фашизма". Роман Пешчаник, стога, можемо читати и као Путовање јунака Е. С.-а кроз простор Средње Европе у време потопа.

Слике с путовања путника Е. С.-а, који је заокупљен мишљу о смрти и идејама како да се спасе (себе и своју породицу) не би ли некако преживео свеопшту хаварију, сликају трагедију једног доба. Читаоцу који би Пешчаник читао као књигу о путовању, са циљем да се упозна са светом који кроз своју перцепцију обликује путник, са духом времена и вредностима које путописац истиче - пажњу би привукле слике Ускрса и ратне празничне трпезе, неправде антисемитске политике, злочина фашизма и његових жртава, међу којима је и Е. С, чија слика унутрашњег света, порушеног под притиском спољашње катастрофе, најбоље одсликава мрак историје у којем су, поред Е. С.-а нестали многи.

Сам писац, Данило Киш, у својим аутопоетичким списима инсистира на истини и на документу који је потврђује, као предуслову за писање. Пешчаник ће назвати археолошким романом, јер га је реконструисао на основу аутентичног писма свога оца, путника кроз простор и време које роман реконструише (у роману ће га именовати иницијалима Е. С.), чиме је обезбеђена веродостојност и истинитост каква се од путописне књиге очекује.

\section{Цитирана литература}

ANTOVIĆ 2007: ANTOVIĆ, Mihajlo. Teorija optimalnosti i teorija metafore u svetlu muzičke i jezičke kompetencije. Doktorska disertacija. Niš: Univerzitet u Nišu, Filozofski fakultet, 2007.

BAHTIN 1986: BAHTIN, Mihail. „Jedinstvo hronotopa”. Polja, br. 330-331, godina XXXII (1986): str. 355-357.

BAŠLAR 2005: BAŠLAR, Gaston. Poetika prostora. Beograd: Alef, 2005.

BOJM 2007: BOYM, Svetlana. „Nostalgia and its Discontetnts”. The Hedgehog Review, vol. 9, br. 2 (2007): str. 7-18. 
BORM 2013: BORM, Jan. „Određivanje puta: O putopisu, putničkoj književnosti i terminologiji”. Philologia Mediana 5 (2013): str. 607-621.

DELIĆ 1997: DELIĆ, Jovan. Kroz prozu Danila Kiša: ka poetici Kišove proze II. Beograd: BIGZ, 1997. [orig.] ДЕЛИЋ, Јован. Кроз прозу Данила Киша: ка поетици Кишове прозе II. Београд: БИГЗ, 1997.

FRAJ 1981: FRAJ, Nortrop. „Književni arhetipovi”. Polja, br. 265, godina XXVII (1981): str. 126-128.

JERKOV 1991: JERKOV, Aleksandar. Od modernizma do postmoderne: Pripovedač $i$ poetika, priča i smrt. Priština: Jedinstvo; Gornji Milanovac: Dečje novine, 1991.

DIMITRIJEVIĆ 2012: DIMITRIJEVIĆ, Bojana (ur.). Filologija i univerzitet. Niš: Filozofski fakultet Univerziteta u Nišu, 2012. [orig.] ДИМИТРИЈЕВИЋ, Бојана (ур.). Филологија и универзитет. Ниш: Филозофски факултет Универзитета у Нишу, 2012.

NEDIĆ 2002: NEDIĆ, Marko. „U porodičnom krugu Danila Kiša”, u Osnova i priča: Ogledi o savremenoj srpskoj prozi. Beograd: Filip Višnjić, 2002. [orig.] НЕДИЋ, Марко. „У породичном кругу Данила Киша”, у Основа и прича: Огледи о савременој српској прози. Београд: Филип Вишњић, 2002.

POPOVIĆ 2007: POPOVIĆ, Tanja. Rečnik književnih termina. Beograd: Logos Art, 2007.

SOLAR 2005: SOLAR, Milivoj. Teorija književnosti. Zagreb: Školska knjiga, 2005.

\section{Извори}

KIŠ 1972: KIŠ, Danilo. Peščanik. Beograd: Prosveta, 1972. [orig.] КИШ, Данило. Пешчаник. Београд: Просвета, 1972.

Maša R. Stanišić

\section{TRAVEL SCENES IN DANILO KIŠ'S HOURGLASS}

Based on a cognitive perspective, departing from a conceptual metaphor, we read the novel Hourglass as a book about journey, and perceived the journey as hero's search of a lost self. E. S. is a traveller who, moving through the world of storytelling novel, tells about himself, about his desires, hopes, inclinations, attitudes towards life, about his intimate world, fears, demonstrating his historical truth of an era marked by the horrors of World War II. E. S.' destination, namely the final point of his journey, was created in hero's consciousness as a long floating on the waves of eternity, which emphasized the hero's Ahasuerus nature in death as well.

Keywords: conceptual metaphor, travel book, identity quest, Hourglass, Danilo Kiš 